\title{
Study on Mechanical Properties of Polyurethane Foam Concrete \\ Gomasa Ramesh
}

\begin{abstract}
Foamed concrete is a special type of concrete and it can be used widely in construction of reinforced concrete structures. this study is very helpful for understanding about foamed concrete and mechanical properties of foamed concrete. Lot of researches are going on concrete material and finally we got foamed concrete. It has lot of advantages compared to conventional concrete. Fluidity and Flowability is very good in the foam concrete. It can be used for low cost of construction of structures. It has high properties and advantages compared to conventional concrete. Manufacturing and Production of poly urethane is very simple and easy. because of their low density it can be used for low-cost construction works. Weight of the concrete is also less compared to other conventional concrete.

Keywords:Poly urethane, Foam concrete, Polyurethane Aggregates, Mechanical Properties, Mix Design, Manufacturing.
\end{abstract}

\section{INTRODUCTION}

$\mathrm{F}_{\mathrm{o}}$ construction of civil engineering structures the main reason for the use of this type of concrete is having high fluidity compared to other conventional concrete. This type of concrete is having high settlement compared to conventional concrete. There are lot of advantages are there for using this type of concrete in construction works compared to others. Many researches are going day by day. In this paper mainly focuses on importance of foamed concrete and its mechanical properties. In this type of concrete cement paste and mortar are used about twenty percentage of its volume. The strength of concrete is also good compared to conventional concrete. It is a light weight aerated concrete.

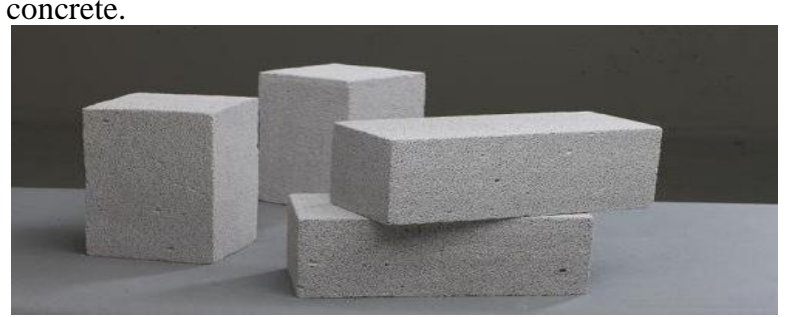

\section{LITERATURE REVIEW}

Mohd Sari 2007 et al.

In this paper author explains about foamed concrete and its applications very clearly. Application and properties are very good compared to conventional concrete. In this paper author explains mechanical properties of foamed concrete. In this author also explains about important factors and applications of foamed concrete.

Manuscript received on 02 October 2021 | Revised Manuscript received on 23 October 2021 | Manuscript Accepted on 15 November 2021 | Manuscript published on 30 November 2021. * Correspondence Author

Gomasa Ramesh*, M.Tech Structural Engineering, Vaagdevi College of Engineering, Warangal, India.

(c) The Authors. Published by Lattice Science Publication (LSP). This is an open access article under the CC-BY-NC-ND license (http://creativecommons.org/licenses/by-nc-nd/4.0/)

\section{Jones 2016 et al.}

In this author explains that stability of foamed concrete and instability of foamed concrete. In this author also explains importance of foamed concrete for sustainable material and construction. Many countries are using foamed concrete because their excellent properties.

\section{Vivek 2019 et al.}

In this paper author explains that importance of foamed concrete and uses. Author also explains that cellular and micro structure of foamed concrete. Author specially explained about its special properties such as physical and mechanical. It is also engineered concrete and extensively used for construction of engineering works.

\section{MATERIALS USED}
1. Cement
2. Fly ash
3. Natural sand
4. Foam
5. Water
6. Admixture

\section{ADVANTAGES}
1. Light weight concrete
2. Low density
3. High strength
4. High Dry density
5. High compressive strength
6. Volume stability
7. Impermeability
8. Freezing \& thawing
9. High workability
10. High thermal insulation
11. Good seismic behavior
12. Lower weight
13. Shock absorbing capacity
14. Replace traditional material
15. Speed up work by using precast panel

\section{METHODOLOGY}

There are different types of methods are available for producing this type of concrete. In this mainly two methods are used. They are as follows;

1.Pre foaming method

2.Mixed foaming method

In this first method, cement slurry or cement paste mixed with the stable foam. This type of mixed foam is called pre foaming method.

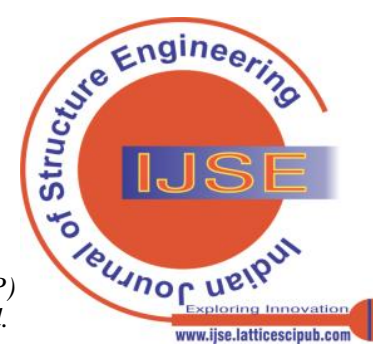




\section{Study on Mechanical Properties of Polyurethane Foam Concrete}

In the second method, foaming is added to the prepare mixture at during the mix process. This type of foaming is called mixed foaming method.

Due to more strength, it can be used for many structural applications. Foamed concrete is different than conventional concrete due to its properties and duration and curing time etc.

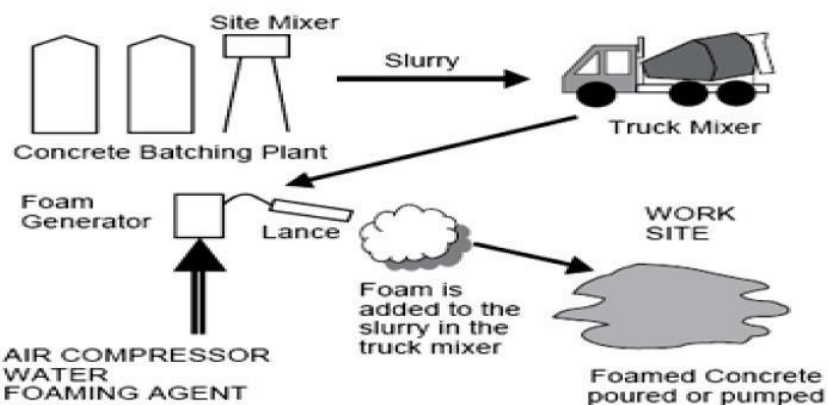

\section{Manufacturing Process} admixtures are mixed to form a foam slurry.

2. Foaming agent is used to create a foam.

3. Next prepared slurry is mixed with the foam to make aerated foam concrete.

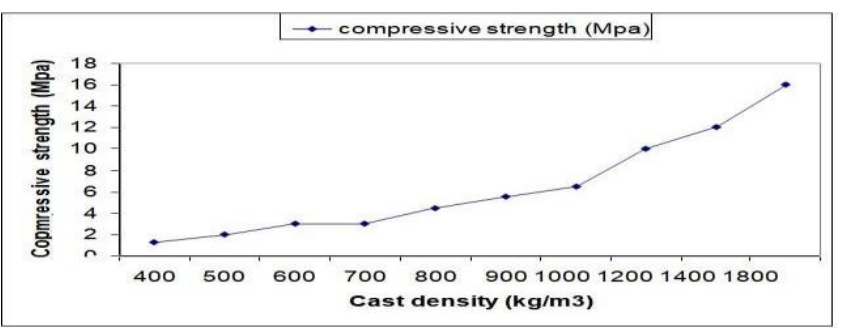

4. After completion, which can be transported into the required site place.

\section{RESULTS}

The results shows that compressive strength of the concrete is increases that with respect to the cast density. With the help of graph know the compressive strength of concrete with respect to cast density.

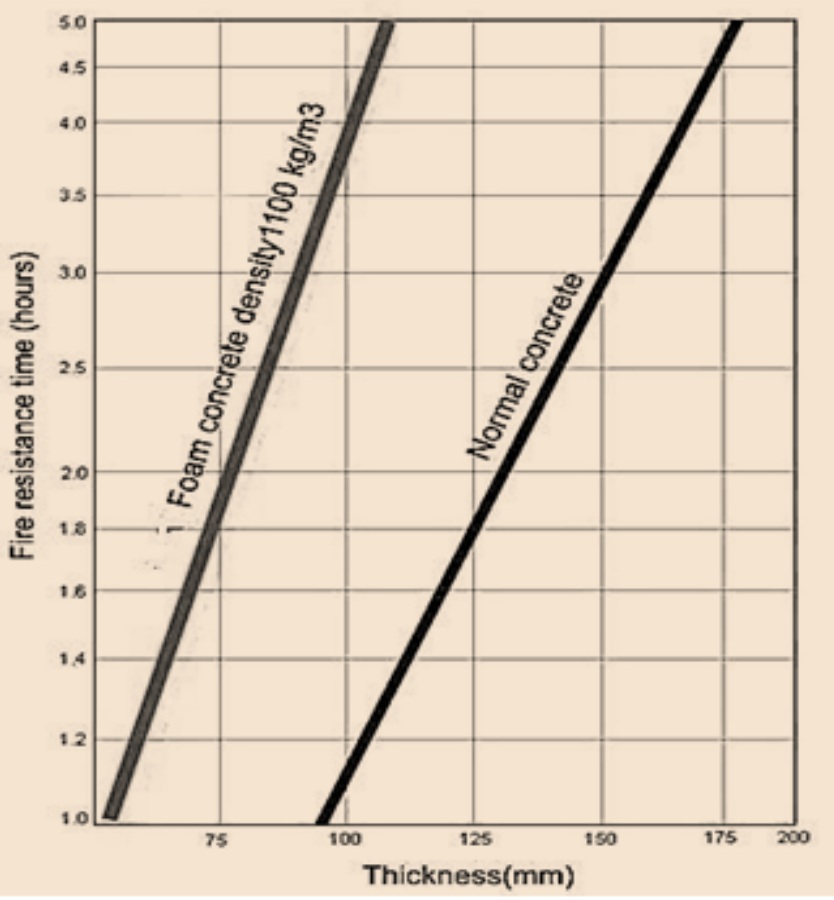

1. Firstly, cement and water and fly ash and

In this above graph we can understand about fire resistance time of foam concrete and normal conventional concrete with respect to the thickness.

\section{APPLICATIONS}

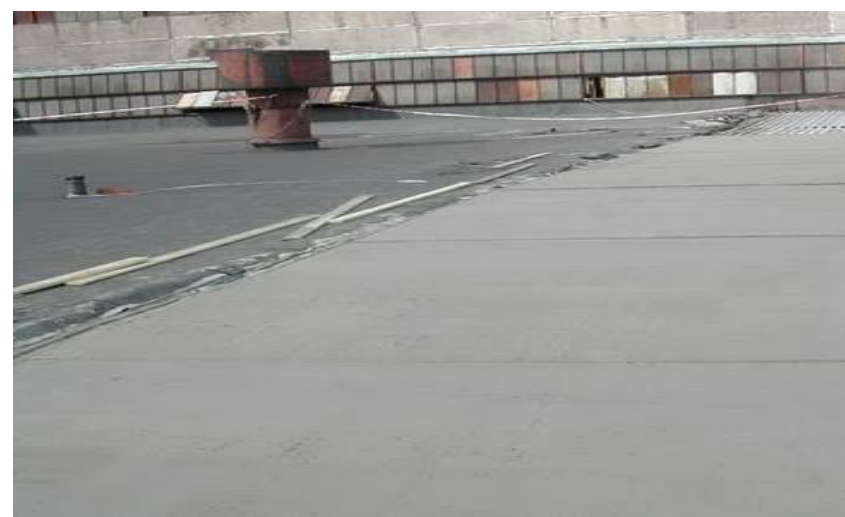

Fig. Roof top thermal insulation and water proofing

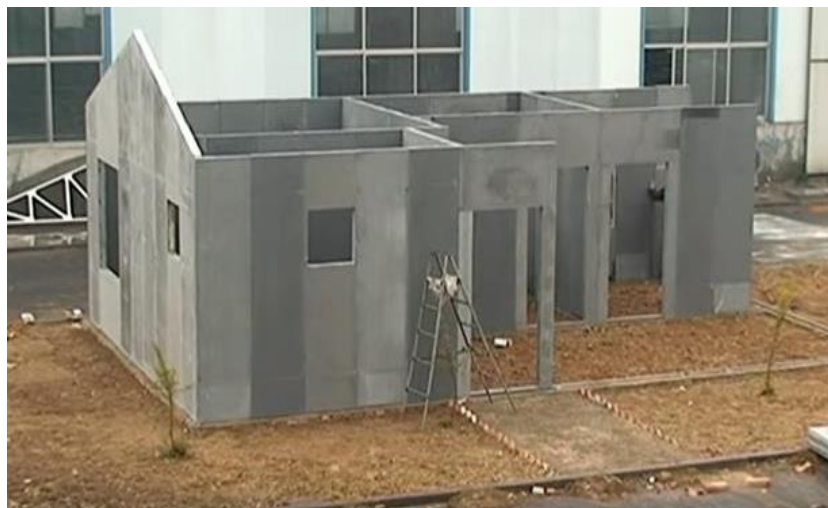

Fig. Load bearing wall with pre cast panel

\section{CONCLUSION}

The major conclusion of this paper is;

1. It is a good construction material

2. Strength is good

3. Thermal properties and insulation properties are good

4. Lower density

5. Weight is less

6. Saving cost of structure

7. Good alternative material for construction

8. High Fluidity

9. High Flowability

\section{REFERENCES}

1. Gomasa Ramesh, Dr. Annamalai Rangasamy Prakash, "Repair, Rehabilitation and Retrofitting of Reinforced Concrete Structures", Special Issue 2021, International Journal of Engineering Research \& Technology (IJERT) ISSN: 2278-0181 Published by, www.ijert.org NCACE - 2020 Conference Proceedings.

2. Dharna Ramya, Gomasa Ramesh and Dr. Annamalai Rangasamy Prakash, "Shear Behavior of Hybrid Fiber Reinforced Concrete", International Journal for Modern Trends in Science and Technology, Vol. 07, Issue 02, February 2021, pp.-79-82, DOI:10.46501/IJMTST0702013.

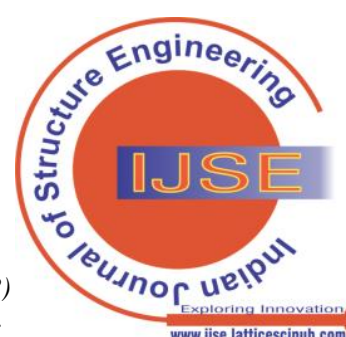


3. Gomasa Ramesh, Dharna Ramya, Mandala Sheshu Kumar; "Health Monitoring of Structures by Using Non-Destructive Testing Methods", International Journal of Advances in Engineering and Management (IJAEM) Volume 2, Issue 2, pp: 652-654, DOI:10.35629/525245122323.

4. Doddipati Srinath, Gomasa Ramesh, "Mechanical Properties of Sustainable Concrete by using RHA and Hydrated Lime", International Journal for Modern Trends in Science and Technology, Vol. 07, Issue 02, February 2021, pp.-83-86, DOI:10.46501/IJMTST0702014 [CrossRef]

5. Gopu Anil, Gomasa Ramesh and Dr. Annamalai Rangasamy Prakash, "An Experimental Study Investigation on Self Compacting Concrete and Strength Properties by using Fiber Reinforcement", International Journal for Modern Trends in Science and Technology, Vol. 07, Issue 02, February 2021, pp.-93-96, DOI: 10.46501/IJMTST07022016

6. SriramojuSravani, Gomasa Ramesh and Dr. G. Dinesh Kumar, "Study on Percentage Replacement of Cement by Glass powder for M20 Grade Concrete", International Journal for Modern Trends in Science and Technology, Vol. 07, Issue 02, February 2021, pp: 129-132, DOI:10.46501/IJMTST0702022

7. Bandi Pooja, Gomasa Ramesh and Dr. G. Dinesh Kumar, "Experimental Study on Mechanical Properties of Geopolymer Concrete by using Fly Ash and RHA", International Journal for Modern Trends in Science and Technology, Vol. 07, Issue 02, February 2021, pp.-50-55, DOI:10.46501/IJMTST0702008

8. Palakurthi Manoj Kumar, Gomasa Ramesh and Dr. Annamalai Rangasamy Prakash, "Evaluation of Different Tests and their Comparisons by Combining Cement with Various Binders", International Journal for Modern Trends in Science and Technology, Vol. 07, Issue 03, March 2021, pp.: 119-122, DOI: 10.46501/IJMTST0703021

9. Bonagani Vamshi Krishna, Gomasa Ramesh and Dr. Annamalai Rangasamy Prakash, "Effect of Geo-Activator on Strength and Durability Properties of Geopolymer Concrete", International Journal for Modern Trends in Science and Technology, Vol. 07, Issue 03, March 2021, pp.: 123-126, DOI:10.46501/IJMTST0703022

10. Gomasa Ramesh, Doddipati Srinath, Mandala Sheshu Kumar; "Earthquake Resistant of RCC Structures" Published in International Journal of Trend in Scientific Research and Development (ijtsrd), ISSN: 2456-6470, Volume-4, Issue-5, August 2020, pp.808-811.

11. Gomasa Ramesh, Doddipati Srinath, Mandala Sheshu Kumar, "Importance of Dynamic Analysis for RCC Structures", International Journal for Modern Trends in Science and Technology, 6(8): 271-276, 2020, DOI:10.46501/IJMTST060844 [CrossRef]

12. Gomasa Ramesh, D Srinath, "Repair, rehabilitation and retrofitting of reinforced concrete structures by using non-destructive testing methods", March 2021, Materials Today: Proceedings, DOI: 10.1016/j.matpr.2021.02.778 [CrossRef]

13. D Srinath, G Ramesh, "Mechanical properties of sustainable concrete by using RHA and hydrated lime", March 2021, Materials Today: Proceedings, DOI: 10.1016/j.matpr.2021.02.785. [CrossRef]

\section{AUTHORS PROFILE}

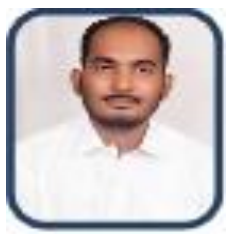

Mr. Gomasa Ramesh, B. Tech Civil Engineering, M. Tech Structural Engineering, Vaagdevi College of Engineering, Warangal, 506005, Telangana, India. Presented and Participated in various International conferences and as well as National Conferences and also Received Best Paper Awards for some Papers and also Received Best Young Researcher Award for 2020. Published more than 15+ Research Papers in

International Peer Reviewed UGC Journals. Received Academic Excellence Awards from Andhra Pradesh Social Welfare Residential School, Manthani during SSC-2011(School First) and also Received Academic Excellence Award from VMR Polytechnic, Diploma in Civil Engineering during 2014 (Class First) and also Received Academic Excellence Award from HITS, Hyderabad during 2017 (Class Second). Selected and Shortlisted for Site Engineer Position to Work with GHMC Housing Board of Telangana (Application Id:14517. Member of various Professional Bodies American Society of Civil Engineers, Structural Engineering Institute, Institute of Structural Engineering, American Concrete Institute and American Society of Testing Materials etc.

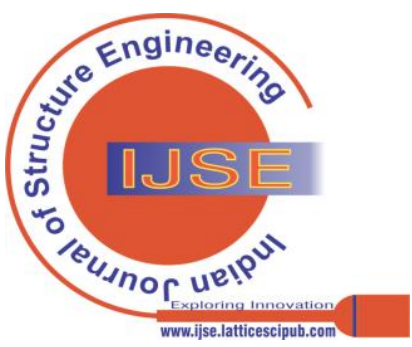

